\title{
MINLNG ACTIVITIES
}

PIPGT DIVISION - Admiraity-Alaske Mining Company has purchasod a Longyoar Volvarino diamond drill with an electrio drive and a gas-driven $20 \mathrm{KW}$ generator to furnigh the power. This is oquipment for the next phase of thels diamond arilling program on thelr nickel-copper ore body at Funter Bay. A dianond drill crew will probably soon be at work with thla new equipiont. The prospect drifting 1s continuing. Activitios of this oonpeny elso include the staking of additionel claims as a result of the aerlal magnetometer survey made over tho area last Bummer.

THIRD DIVISION - The Aleske Oopper Mines Company exploration project at Maclaren RIver wag closed down for the winter. Although large quentitles of copper ore of commercial velue hes not yet been found, they intend to resume work at the oarliest possible date in the oming.

FOORTH DIVISIaN - A well-known Canadian mining group has reportediy taken an option from the DeCour aey Mountaln kining Compeny on their meroury holdings along the lawer Kuskokwion RIver. They ero plenning an exploration program before putting the properties into production. The group's serious intentions are indicated by the pect that they are also roported to be plcking up other meroury prospects in the Kuiskokrim Velley. Former DeCoursey atockholders are recoiving stook in the now enterprise, according to information releaged.

\section{OIL NEWS}

A news reloase early in Decomber announced that Richfleld oll Compeny has entered the Aleskan leasing activities. They appliod for loabes on 90,520 acres of Kenal Peningule land.

Shell 011 hes also leased over 90,000 acres on the Kenal Pentnsule lately. This is a slgnifioent more bocause Shell has had geologlcal fleld parties worklng in that area most of the pest fleld season.

Loases on gnother 65,000 aores of Kenal Peningula land were applled for during Decamber by ing independent Anchorege residents.

A now area in oll activity was that of Birohwood, 21 miles north of Anchorage, Two applications for leasea of acreage there were tilod by Alaske Natural Gas and Petrolewn Compeny, of Anchorage, and one by three Blrchwood residents.

On Decomber 2, it was reported that the Fllilips Petroloum Compeny's second hole, near Ioy Bey, was down to 6550 feet. This hole is nemed Sullivan No. 1

\section{PYRITE INFORMATION}

It has been stated many timeg by the TDM thet pyrite deposits were beocming more valuablo with the advent of new motallureical processes by mion the iron as 
well as the sulfur is saved. There is now a now raduotion plant in operation at tho Norenda MiDeB in Quobeo which rocovers sulfur, 1ron, and sulfur-dioxide ges from pyr1te. It 18 a pliot operation only, at present, with a capacity of 370 toll of pyrite per dey, but w1ll no doubt be inoreased as they get the "bugs" worked ont." Again, it ehould be emphesized that the Alesken miner oan hardiy expect to mine aild abip pyrite blmself at a profit, but sulfur compenles who oan do it are interested in purobeging or leasing good pyrite prospects.

\section{RADIOACTIVE DNEORMATION}

As a result of a flood of letters during the pest two months esking for information on redioactives in Alagka, we have mimeographed an information circular on "ihe subjeot. It is Tus Information Circular No. 4, "Aleske Uranium Information." It contalis mostly tho samo information as publishod in the "Uranium" chapter of the November TDM Bullotin with a littlo edditional 1nformation and a list of USGS Trace Flements ofrculars that may be obtelned on thelr work in investigating redioactires in Aleaka. These USGS circulars are generel in nature, and usually do not go into extensivo datall. The TDM circuler 18 free upon request.

There hee been an objection to our too-brief comparison of celger and sointilletion counters in the above-mentloned Information Circular No. 4 and November TMA Bulletin in which we state that the sointillation counter is 50 or more times as sensitive as the Geiger counter. This statemsnt is tmue for a good scintillation counter as agalngt an ordinary celger counter with only one GelgerMuller tube, but is not true for eny sointilletion counter over any Gelger counter. Multiple tube Gelger counters are mede that are as sensitive as comparatively pricod portable sointillation outfits. It 1a reported further that they aro even preferable to the sointilletion counters under some conditions, and that the solntillation counters are more fragile and prone to digruption of service, whioh of course would entall more lost time and repelrs. Ve hope this will olarify tho sltuation and eppropriate corrections wil be made when a reprint of Information Clroular No. 4 is necessary.

The USGS recently released a brief technlcal report on solntiliation oounters ich may be of 1nterest to persons purohasing or using them. It is Goologiaal Survey Circular 353, "Portable Scintillation Countera for Geologic Uge", and oan be obtalned free on application to the Geologioal Survey, Waghington 25. D.C.

\section{QUOTE BY SECFRTARY MCKAY}

In an address at a meoting of the Menufeoturing Chemigta' Assoclation, New York C1ty. November 23, 1954, Secretary of the Interior Dougles McKay sald tho fol.jowlag which 18 very true and perticularly appropriate when consideled in the light of Alaska's problem:

We would be in error if we regarded the resource chellenge of the ruture as only a scientific puzzlo. While meny of the answers to our resouroe problems, it is true, coms from the research laboratory, history has shown that even tho most promiaing 1deas and discoverles 12 ocme to nelught 11 the ooonomic and political olimate in whlch they can grow and come to fruftion is lecking." 


\section{SUGGESTIONS FROM RRADERS}

The TLM hes received geveral letterg from our readers containing suggestions for pumps and pipe, oto., that might be used to an adventage with our idea of prospecting by groundsluloing a presented last month. We appreciate these letters and suggestions. There will be a report on the matter in a future issue.

\section{ITEMS FROM THE VESTIRN MINER}

Two items by the "Sourdough" in the December Western Miner and Oll Reviaw are worthy of repeating this month. The first item concering a telk by Charlie Steen of Colorado Plateau uranium fame, and the second concerns prospectors burros. In the Sourdough's own words:

"At this meoting he expressed an opinion I have always had; namely, that when It comes to the matter of discovering new mineral deposits, this industry mugt depend on the prospector. He went on to explein that there has been a great deal of talk about modern devices, such es airborne magnetometers, scintillometers, Gelger counters, Pluorescent lamps, blogeochemical methods, etc., but that these devices should be kept in their proper perspective--they are aids to the prospetor, valuable as they mey be, but they do not and canoot replace the important work of the prospector. He expressed the opinion that this 1 dea 1 s becoming more generelly accepted emong the heads of large mining exploration oompanies in the United statas. It is my opinion that the danger in losing sight of the importance of the individual type prospector is that it mey cause a slackening of interest in prospecting among Canade's younger generation ond be responalble for certain restrictive and unwise legislation affecting the prospecting for, staking and development of new mineral deposits........

"Recelved a letter a lew days ago from Miss Alma Diebolt of the Select Shc ping Service, 615 West Pender St., Vancouver, telling of the small Mexican burros which she thought might be sultable for pack animals for use in prospocting and mining operationa. These burros are appoximately 37 Inches high when full grow, are seid to be gentle, essy to take care of, eat grass and hey, like carrots, oranges and tobecco! They are seid to be very hardy, Iive a man's lifo span and IIve very well in any climate. Misa Diebolt advises these donkeys are used quite extensively in some perts of the country for packing supplies into mining propertios that are inaccessible by other means. Her firm imports these donkeys and delivers them in Vancouver or nearby for 150 . It 1s understood 14 of them are already in British Columbia and more are on order."

\section{NICKEL}

Nickel is one of the strategio metals in which the United States 1s criticelly dericient, especially in terms of domestic production. While we have consumed over 60 percent of the nickel production of the free world since 1940, more than 99 percent of this has come from forelgn sources. During 1953, for instance, total consumption of nlckel in the United States was $211,361,463$ pounds, while domestic produotion amounted to only 3,203,000 pounds, largely recovered as a by-product of copper rofinfing. Total Canadian production in 1954 is eqtimated et 320 million pounds of the metal, elmost all of which comes from mines of two companies, International Nickel and Falconbridge. A considerable part of this Canadian production goes into U, S. stockpiles. International Nickel has a contract wIth the $\mathrm{U}$. S. to supply 24 miliion pounds yearly in adaition to what is already 
going 1nto the stockp1les, and Falconbridge has contracted to sell the U. S. 150 mililon pounds in a period of elght yeers, with optiong to sell an additional 125 milifion pounds. This gives an $1 \mathrm{deg}$ of the amount of U. S. money going into Canadian mineral resources. Another contract calls for the sale to U. S. General Services Administration of 4.5 million pounds of refined nlckel by August, 1955.

The resistenoe of nlckel to corrosion forms the principal basis for its many industrial applioations. In many instances, however, alckel is the unseen motal, contributing vital properties to an alloy, but recelving little of the credit afforded the rinlahod product. In addition to its corrosion-resistant properties, nickel controls to a degree the strength, duct1lity, toughness, hardness, electrical resistance, magnetic properties, thesmel expansion, and mechinability of 1ts varlous alloys.

The price of nlckel has fluctueted botween a high of 3.50 per pound in 1873 down to 21 cents per pound in 1895. W1th consolidat1on of the lerge nickel interests the price bas remained relatively constant, and unlike most metals nickel increased only a few cents per pound durlae the period 1914 to 1918 and acturlly dropped during the second World Var. The oursent price is stabllized at near 64-1/2 oents per pound, after a recent raise from 60 cents.

Nickel has been reported as an essentlal conet1tuent of 89 minerals and as an accessory in many others. It is found commonly as 8 sulfide, arsenide, or a bydrated silicate; never in the netive state. Nickel elloyed with ifon occurs in me. orltes and in placer sands from varlous parts of the world. The princlpal miiclels of nlckel are: the sulf1des, pentlandite $((F \theta, N 1) S)$, polydynte $\left(N 13_{4}\right)$, and millerite (NiS); the arsenldes, niccolite (NiAs), and chloanthite (NiNs 2 ); and the hydrated allicate of nickel and magnesiur, garnier1te. Pentlandite and garnlerite are the most important ore minerals.

While nlckel deposits have been found in many places throughout the world, most of them are too low grade to be handled profitably by the present known methods of processing. The largest known deposits are centered in canada, Cuba, New Caledonle, Norway, and tho U.S.S.R. In 1875 the lateritic nickel depositg of New Caledonia were opened and until 1905, when Canada emerged as the principel source of nlckel, these deposits dominated the world market. The Sudbury deposits in Cangda now bocount for about 90 peroent of the fres world production.

The nlckel depogits of the world mey be separeted into two different types, besed upon mode of origin and mineral composition. These are: (1) the primary ores, comprlsing the nickel-bearing sulfiobs, and occurring as magmatic segregations or deposited by rising solutions in veins; and (2) the secondary or lateritic ores whioh were concentrated by descending solutions and form residuel oeppings on ultramafio rooks that originally contained small percentages of nickel.

The 1mportant primary nickel sulfide ares, of which the rich deposits of Sudbury, Canade, are examples, are almost always assoclated with basic intrusive 1goous rocks, such as gabbro and diorite. The principel ore minerals are pentlandite ( $(\mathrm{Nl}, \mathrm{Fe}) \mathrm{S}$ ) and chalcopyite (CuFes $)$, which occur intinately assoclated with pyrrbotite (FeS). They are usually worted for both nickel and copper, and commonly oontein minor amounts of cobalt, selenium, allver, tellurium, and platinum whlch may also be recovered, 
The Sudbury deposita are localized elong the perlphery of a pre-Cambrian leneous body which has intruded older sedimentary rooks. This body, which orops out In a great ellipge 36 miles long and 20 miles wide, is presumed to be spoon shaped. Numerous faults offset the normal intrusfve conteot from a few feet to as mich as $2-1 / 2$ miles. The intrusive is in threo distinct layers with norite, $\theta$ bas. : 18neous rock of the gabbro family, at the bese. The ore bodies are confined to the zone of contect with the underlying rocks or, in some inatances, alone the offsets. The minerelization for both contact and offset deposits occurs in the diseominated form, as stringers in the host rooks, as velns along shears, as tho matrix in brecola zones, and as lenses of clean sulfide ore. Other important deposits of this type are located In Carada, Union of South Africa, U.S.S.R., Norway, and in the United Stateg.

Alagke hes excellent alckel possibillties as typliled by the well-known deposits at Funter Bay and Yakobi Island in Southeast Alsaka and the Spirit Mountain deposit in the Copper lidver country. A promising belt of nlckel prospets exists from Yakob1 Island down the west coasta of Chlchagor and Beranof Islande to Snipe: Bay whlch the TDul has long advocated should be thoroughly prospected by private interest8. Nickel prospects are also known in many other sections of the Territory.

The larger Alaskan deposits are of the prinary orlgid. They mostly oocur as parts of norite 1ntmsiong and are either suifides disgeminated through the norite mess or concentrated lenses or pode of nearly solid sulfides. The sulfides are usually pyrrhotite, pentlandite, and chelcopyrite. The meterlal is usually quite magnetic, relative to the surrounding country rock, wheh allows a simple adaitionel thad of prospecting for 1t. It should be remembered that nickel is very likely to be associated with pyrrhotite, and in prospecting, eny pyrrhotite mineralizetion should be checked. One nickel deposit was examined by a TDM engineer during the past season which has garnlerite es the chief mineral. A clessification of this deposit has not yet been made. Several USGS bulleting deal exclusively with Aleskan nickel deposits. Tests for nickel were given in a previous TDi Buljetin. Huch of the 1nformation in this article on alckel deposits, other than Alaskan, was "Ilfted" Prom the November issue of the Calfforala Division of Minos Monthly Mineral Inf:-rmation Serviod.

\section{URETAL PRICFS}

The following metel prices are taken from the weokly E. and M. J. Metel Markets reports of detes as indicatod to show current prices as all as trends:

\begin{tabular}{|c|c|c|c|}
\hline & $\begin{array}{l}\text { Dec. } 30, \\
1954\end{array}$ & $\begin{array}{l}\text { Month } \\
\text { Aso }\end{array}$ & $\begin{array}{l}\text { Year } \\
\text { Ago }\end{array}$ \\
\hline Copper, per 16. & $29.7 d$ & 29.78 & 29.7 .0 \\
\hline Load, per lb. & $15 \phi$ & $15 \phi$ & $13+1 / 2 \phi$ \\
\hline Zinc, per ib. & $11-1 / 2 \phi$ & $11-1 / 2 \phi$ & $100^{\circ}$ \\
\hline Tin, per $1 b$. & $87-1 / 2 \phi$ & $90-7 / 8 \phi$ & $85-I / 4 \varnothing$ \\
\hline Quicksilver, per flask & $\$ 322-324$ & $\$ 318-322$ & $\$ 187-189$ \\
\hline Silver, per oz, & $85-1 / 4 \varnothing$ & $85-1 / 4 \not$ & $85-1 / 4 \varnothing$ \\
\hline $\begin{array}{l}\text { Platinum, per oz. } \\
\text { Nickel, per lb. }\end{array}$ & $\begin{array}{l}\$ 78-84 \\
64-1 / 24\end{array}$ & $\begin{array}{l}377-84 \\
64-1 / 26\end{array}$ & $\begin{array}{c}\frac{81-93}{60 d} \\
\frac{1}{6}\end{array}$ \\
\hline Molybdenum, per 16. & $\$ 3$ & $\$ 3$ & 33 \\
\hline Tungeten ore, per unit & $\$ 63$ & 63 & $\$ 63$ \\
\hline
\end{tabular}

